\title{
Exploration of Solutions for Revitalisation of Rural Areas in South Africa
}

\section{Dr Daniel Francois Meyer}

North-West University (NWU), South Africa

Email:Daniel.meyer@nwu.ac.za

\section{Doi:10.5901/mjss.2014.v5n4p613}

\begin{abstract}
Rural regions in South Africa need revitalisation. This paradigm shift is due to overpopulation and congestion in urban areas, technological advances leading to "space shrinking", a growing need for food security, and a need for a sense of community and belonging. Since 2011, the national State of the Nation addresses (SONAs) in South Africa have focused on rural development as one of the main priorities of government, a neglected practice for more than two decades. This article analyses the state of rural development policies in South Africa and provides solutions for improved implementation. Government policies have been analysed and a need for improved rural development coordination is required. Possible solutions provided include categorising of rural regions, the "Feza iSimangaliso" rural development model, and rural development best practice principles and procedures.
\end{abstract}

Keywords: revitalisation, rural development, job creation, local economic development (LED), local government, South Africa.

\section{Introduction}

This study seeks to explore possible solutions that would allow for the revitalisation and development of rural areas in South Africa. Rural South Africa has deteriorated consistently over the last few decades. The main reason for this phenomenon is urbanisation. Rural areas are competing with larger cities, with comparative and competitive advantages, identified globally as engines of growth due to skewed resource allocation. Turn-around strategies are required to ensure that rural areas provide economic and social opportunities for local communities (DRDLR, 2010a).

Globally, as many as 1.4 billion people live in extreme poverty at less than $\$ 1.25$ per day and more than two-thirds of them live in rural localities in developing countries. Despite large-scale urbanisation, poverty remains largely a rural problem, with up to 70 percent of the world's poor living in rural settings (IFAD, 2011). In South Africa, 43 percent of the population is regarded as rural and 57 percent as urbanised. The average rural population for Africa is approximately 60 percent, and for developed countries, the level of urbanisation is approximately 80 percent (Nationmaster, 2011). According to Hemson (2004), approximately 70 percent of the poor population in South Africa live in rural areas. Mokopanele (2006) confirms this and states that half of all households in South Africa have to survive on less than R 20 per day; of these up to 70 percent of the approximately 5,2 million households who live on R 20 per day, reside in rural areas.

The two main priorities of the South African government are job creation and rural development. In October 2011, the National Planning Commission (NPC) released its diagnostic report (the National Development Plan), which lists the main priorities that are linked to national priorities (The Presidency, 2011). In October 2010, the New Growth Path (NGP), was released (Chabane, 2010). The NGP supports the national priorities and is aligned with the findings of the NPC. The focus of the NGP is on job creation, poverty alleviation, infrastructure development, agriculture, and rural development. In collaboration with these policies, the Comprehensive Rural Development Programme (CRDP) was formulated and released in 2009 as a strategy focused on rural development (DRDLR, 2010b).

Rural revitalisation and development is a complicated process, and an integrated and comprehensive process is required for success. Most issues link to economic planning and strategic spatial planning. These two tools, in conjunction with others, could play a key role in the revitalisation process (OECD, 2007). According to the DRDLR (2010), the situation in rural South Africa is dire and complicated and intensified efforts of rural revitalisation are required to turn this situation around. 


\section{Concepts, Definitions and Provisional Solutions}

According to Kenyon (2008), rural areas require revitalisation. He defined rural revitalization as, "a process which seeks to reverse rural decline, to develop a more resilient, sustainable and diversified local economy, and to enhance the quality of life of rural communities." Furthermore, revitalisation needs to focus on the creation and stimulation of opportunities that will generate income and jobs, while preserving and enhancing the unique dynamics and features that make rural life special. Kenyon (2008) states that the positive outcomes sought by rural revitalisation include aspects such as stabilising and increasing the local population, diversifying the economic and employment base, maintaining an acceptable level of service, and preserving special rural attractions.

According to Wilkinson (1986), rural areas have three main problems, namely, the lack of social and community facilities, they appear to be out of fashion, and there is a lack of efficient policies and strategies to encourage rural development. Wilkinson provides some solutions to the phenomenon of rural revitalisation, namely the creation of jobs and generation of income, quality services and infrastructure, the reduction of inequality within the local community, and informed and committed local leaders. Wilkinson (1986) further states that, over the last few years, rural localities have become more popular due to over-congestion in cities, the move away from manufacturing to service industry, and the possibility of local solidarity in a rural community.

According to the OECD (2006a), "Rural areas face several new opportunities and challenges which call for appropriate rural development policies and a more efficient use of scarce resources." Definitions of rural areas include that they are sparsely populated, possess limited educational and other community services, are areas where people farm or depend on natural resources, land is cheap, and transport costs are high (Heimann, 2010; Buxton, 1976; Duxbury, Campbell \& Keurvorst, 2009; and Ashley \& Maxwell, 2001).

SARDQ, (2004) defines rural development as "the positive advancement of rural people in rural areas through improvement of rural institutions and systems, expansion of rural infrastructure and growth in rural economic activities for a better quality rural life." According to the World Bank (1997) rural development is "a process leading to sustainable improvement in the quality of life of rural people, especially the poor." Rural development can make a powerful contribution to the four critical goals of poverty reduction, namely wider shared growth and development within a specific rural region; access to basic needs; food security improvement; and sustainable natural resource management.

In terms of the Integrated Sustainable Rural Development Strategy (ISRDS)(The Presidency, 2000), rural development is defined as multi-dimensional and a much broader concept than poverty alleviation by means of economic and social programmes. The ISRDS places focus on changing environments to enable an increase in the income levels of the poor, investment in local communities, and contribution to the maintenance of social infrastructure. A successful rural development strategy will make people less poor, rather than comfortable in their poverty. Rural development aims at improving the countryside or peripheral areas, with a mostly agrarian character. Characteristics of the rural poor include a lack basic needs, inability to improved their quality of life due to social exclusion and poor governance, limited land ownership or access to capital and employment, stagnating economy, underdevelopment of agriculture, lack of quality services and poor health conditions (Kakumba \& Nsingo, 2008; Djukanovic \& Mach, 1975).

Heimann (2010) lists the following rural challenges in South Africa, namely the underutilisation and sustainable use of local natural resources; poor access to socio-economic facilities, public services, infrastructure and other essential services; the low levels of skills; unresolved land reform and land ownership issues; and the unexploited opportunities in labour intensive industries such as agriculture, tourism, mining and manufacturing. South African rural areas are characterised by traditional agricultural processes, low income families, lack of finances, a lack of technical skills, and a high percentage of poor people, largely black (Bester, 1994).

No universally accepted definition for the term rural, rural towns and urban centres in rural settings exist, because a specific country's national spatial structure influences any definition. In countries with huge populations such as India and China, a small rural town could have a population of up to 100000 people, whereas in countries with small populations, a small town could have 2000 to 10000 people. It is common to use population thresholds for the categorisation of rural nodes serving the surrounding region. Another method of classification is based on the diversity of functions delivered within the nodal area and the surrounding region (Tacoli \& Sutterthwaite, 2002).

In South Africa, a small rural town is defined as an urban area, formally planned and surveyed, with at least a range of public and private service providers such as retail, institutional and professional services, and inhabitants ranging from 1000 to 35000 people. Small town revitalisation is an infusion of new energy that will give the rural town allure (COGTA, 2010). Small and medium sized rural towns, play a very important part in the local economic landscape. A large proportion of the rural population resides in these towns, which also host a large share of the local non-farming 
economic activities (Tacoli \& Sutterthwaite, 2002).

Regional spatial planning plays a key role in small town and regional linkages. The traditional divide between urban planning and rural development is a major constraint in urban/rural linkages (Tacoli \& Sutterthwaite, 2002). Rural development is neglected in an "urban bias" approach in regional spatial planning. The inter-linkages and dependencies between urban areas and rural areas are in most cases neglected (NRI, 2004).

Potentially, involving local communities in rural development programmes will enhance livelihoods and accelerate development. Public participation forms part of "New Public Management", which seeks to re-invent government by breaking rigid, traditional bureaucratic structures, opening government to transparency and accountability (Kakumba \& Nsingo, 2008). Indigenous knowledge is of key importance for development of local communities (Makhura, 2004). Generally, it is accepted that local economies, based on applied knowledge of local conditions, are more successful.

Rural development, local economic development (LED), and the creation of partnerships are key components in revitalisation of rural areas. The benefits of forming partnerships at the local rural level includes acceleration of new innovation, ease to establish new local partnerships, each partner shares in the benefits of the process, ensure access to more resources, and partnership formation improves transparency and accountability (Rogerson, 2009).

Myrdal (1957) states, "It is in the agricultural sector where the battle for long term economic development of a region will be won or lost." The agricultural sector is of major importance for rural development. Agricultural supply chains need improvement and reform to move from traditional to modern methods of agricultural production are needed (Henson, 2006). In traditional economic development theory, the agriculture sector plays a supportive role, providing sufficient low-priced food and labour to the industrial economy. The agriculture sector used to play four specific roles in economic development, namely provide inputs for industrialisation including agro-processing, contribution to foreign exchange, provide rural communities with income and assist with capital investment (Todaro \& Smith, 2011). Herrick and Kindleberger (1995) argue that improved access and ownership regarding agricultural land in rural areas, is critical for rural development.

Effective institutions could assist in creating an enabling economic environment in the rural and urban areas of a rural region. Improved institutionalisation can be achieved by means of inter-sectoral communication, strengthening local government, high levels of community participation, improved links between communities and politicians and partnership development (Davis, 2004).

According to Todaro and Smith (2011), the key requirements for rural development strategies include:

- Improve the quality of life of rural people by increases in small-farmer output, productivity and food security.

- Technology and innovation such as tools, irrigation, and fertilizers.

- Incentives and pricing policies.

- Institutional support.

- Increase food production and promote a wider spread of benefits of agriculture.

- Land reform processes to benefit the poor portion of rural areas.

- Provide access to credit.

- Promote non-farming incomes through industry and agro-processing.

- Provide education and health facilities.

- Ensure environmental sustainability.

- Transport, infrastructure, communication and education should be the focus of investment priorities.

According to De Satge (2010), key issues for successful rural development include the involvement of local communities in the planning and implementation process, understanding local gaps in livelihoods, provision of basic needs, risks and vulnerability. Other factors listed are to ensure interventions with minimum input and maximum results for the majority of local people, and optimisation of innovation and learning.

Possible rural planning proposals for sustainable livelihoods could include decentralisation of planning decisions, funding and responsibility to local role players, promotion of people-focused and poverty-based planning, expansion of local capacity for LED, conducting poverty audits, the inclusion of local knowledge in planning processes and decisions. The development of strong communication channels between officials, councillors, community development workers (CDWs) and the public (ward committees) is also of importance (IIED, 2000).

Delius and Schirmer (2001) list some possible solutions to rural development in South Africa namely: the capacity of the state must be maximised within an integrated approach, a change in the structural position of rural people by government is needed, such as access to economic opportunities and infrastructure development, regarding land reform and agricultural development policy, capacity of provincial and local government officials is very low, and alienation of farm land is a slow and expensive process. Such policy should totally transform the rural crises. The provision of basic 
services to rural people is critical and welfare provision such as old age pensions and disability grants. Rural people should be assisted to help themselves. Government must provide encouragement, funding and expertise to local organisations and play the role of a facilitator.

The DRDLR (2010a) conclude that the following issues regarding rural development and revitalisation are required, namely that the future of a rural area lies in its people and future plans. It requires time, energy and dedication from all role players in political direction, aligned planning, policy and implementation. A dynamic local community taking control of their own situation and affecting changes provides the best chance of success.

Most rural development strategies and projects do not have the required impact, as they are not spatially referenced. A rural development strategy must attempt to lessen the impact of apartheid policies regarding access to jobs, distribution of assets and economic and spatial marginalisation. Building an asset base is important for poverty reduction and includes improved access to basic services and safety nets, improved local skill levels, and integrated housing development to reduce transport costs and allow economic opportunities (Sibisi, 2009).

De Satge (2010) lists rural development strategies for South Africa that include, to re-invigorate the land reform process/projects, address shortcomings in policy, support mixed farming and emerging farmers, streamline ownership to productive units, ensure the availability of water and irrigation for farming projects. He also lists access to capital, as well as incentives, mentors and skills promotion, develop infrastructure, allowance for good market access and the availability of information as important.

Rural development also has a strong social component. Netshitenzhe (2011) listed government interventions to address rural poverty, which included social grants, free basic services, housing, skills training, wage subsidies, public employment programmes, support for micro enterprises and entrepreneurs, and full time employment opportunities. The United Nation Development Programme (UNDP, 2012) defines the "rural triple wins model" as consisting of three components, namely economic development, social development and sustainable development. The aim is to include all three components in any rural development strategy and project to allow for inclusive growth, with jobs resulting in improved quality of life of rural communities and support for the green economy.

The following section provides an overview of rural development policy in South Africa.

\section{South African Rural Development Overview}

Rural development and land reform are focus areas for the South African government. The revitalisation of rural towns has been identified as critical in government efforts to revitalise the economies of rural regions. Rural towns play a vital role in the creation and strengthening of linkages between rural and urban areas. Rural areas, including rural towns, are experiencing an economic decline, mainly due to the impact of urbanisation and globalisation. The majority of rural towns lack external linkages and activities that can assist in dynamic economic activities. Many of the rural towns are failing as support centres for sustainable economic services to surrounding rural areas (DRDLR, 2010a).

Rural regions and towns in South Africa are characterised by high levels of unemployment, the under-utilisation of local resources, a decrease in agricultural activities, lack of linkages and transport routes, decay in maintenance of infrastructure, lack of community facilities, inability to generate a sustainable income base, and a lack of spatial and land use planning. Although rural towns are seen as potential growth points for rural development, the perception is that rural areas and rural towns have been neglected when compared with urban and metropolitan areas in South Africa. Rural towns are struggling to provide the basic level of service delivery required, and there are limited efforts to provide an enabling local economic development environment by local government (Meyer, 2013). In the past, rural development efforts have been poorly coordinated between the different spheres of government and implementation occurred in an ad hoc manner (DRDLR, 2010a).

With the repeal of all apartheid legislation from 1994 to 1996, the focus of the new government was to improve the quality of life of the disadvantaged rural poor, introducing a number of rural development initiatives, as listed below.

The Reconstruction and Development Programme (RDP) was released in 1994 to actively address the imbalances created by the apartheid era, with one of the key components being rural development (ANC, 1994). The RDP was based on five pillars, namely to provide in the basic needs of people, building local economies, development of infrastructure, promoting peace and stability, and promotion of human resource development. The RDP listed development targets impacting on rural development such as job creation, building of houses, provision of services and infrastructure, and the distribution of 30 percent of agricultural land to emerging farmers. The programme failed due to uncoordinated implementation and duplication by government agencies (DRDLR, 2010a).

The Integrated Sustainable Rural Development Strategy (ISDRS) of 2000 (The Presidency, 2000) was introduced 
to address the uncoordinated efforts of the RDP. The ISRDS had a rural development vision based on the creation of stable rural communities with viable institutions, sustainable economies, access to social amenities, and the ability to attract and retain skilled people to ensure rural growth and development. The idea was to have successful rural development by means of participatory and decentralised planning and implementation. The need for a spatial plan to guide the national investment and development programmes led to the formulation of the National Spatial Development Perspective (NSDP). Introduced in 2003, the NSDP aimed to address the spatial and economic imbalances of apartheid policies. Other important issues contained in the NSDP include, to provide a spatial framework of the national space economy by indicating areas of severe need and those with development potential, to act as a national guideline for sound spatial principles, to act as a spatial development vision in line with the Development Facilitation Act (DFA), and to identify key areas for infrastructure investment (DRDLR, 2010a; The Presidency, 2003).

The national Cabinet approved the Comprehensive Rural Development Strategy (CRDP) in August 2009. This is the latest rural development policy, different from previous plans in that it is a pro-active, participatory and communitybased planning approach, rather than an interventionist approach. The vision is to create vibrant, equitable and sustainable rural communities. The CRDP intends to reduce poverty, malnutrition, unemployment and lack of infrastructure capacity in rural South Africa. The CRDP is based on three pillars, namely agrarian transformation, strengthening of rural livelihoods and land reform. The goals include accelerated distribution of the country's agricultural land, creation of rural business opportunities, and expanding opportunities for women, youth, disabled and the aged. The concept is to allow rural people to take control of their own destiny and to adapt their indigenous knowledge to their advantage. Priorities of the CRDP include a review of the land reform process, review of the rural land acquisition models, and increase in the pace of settling outstanding land restitution claims. The CRDP process has three phases, meeting the basic needs of rural communities, large scale infrastructure development in rural areas, and the emergence of small, medium and micro enterprises (SMME) development in rural industries and village markets (DRDLR, 2010a).

Various national government departments are involved in rural development. Table 1 lists the main departments in South Africa.

Table 1: Summary of main South African government departments involved in rural development

\begin{tabular}{|c|c|}
\hline Department & Programme/Mandate/Aim \\
\hline $\begin{array}{llr}\text { Department of } & \text { Rural } \\
\text { Development and } & \text { Land } \\
\text { Reform (DRDLR) } & \\
\end{array}$ & Comprehensive Rural Development Programme (CRDP) \\
\hline $\begin{array}{l}\text { Department of Agriculture, } \\
\text { Forestry and Fisheries (DAFF) }\end{array}$ & Develop agriculture as an economic sector linked to all other economic sectors \\
\hline $\begin{array}{l}\text { Department of Economic } \\
\text { Development (EDD) }\end{array}$ & $\begin{array}{l}\text { The NGP is the main policy document, placing job creation at the centre of the national development } \\
\text { strategy as inclusive, equitable employment is central to economic development }\end{array}$ \\
\hline Department of Tourism & $\begin{array}{l}\text { In } 2012 \text { a national rural tourism strategy was formulated with the focus on development of rural tourism } \\
\text { products and prioritise rural spatial nodes with growth potential }\end{array}$ \\
\hline $\begin{array}{l}\text { Department of Trade and } \\
\text { Industry (DTI) }\end{array}$ & $\begin{array}{l}\text { As part of the DTI, two agencies of importance regarding rural economic development exist, namely the } \\
\text { Small Enterprise Development Agency (SEDA) and the Industrial Development Corporation (IDC) } \\
\text { which is managed by the Department of Economic Development but links with DTI }\end{array}$ \\
\hline $\begin{array}{l}\text { Department of Cooperative } \\
\text { Governance and Traditional } \\
\text { Affairs (COGTA) }\end{array}$ & $\begin{array}{l}\text { To improve coordination across the three spheres of government for faster and improved service } \\
\text { delivery. The concept of cooperative governance is promoted through greater emphasis on working } \\
\text { with communities }\end{array}$ \\
\hline $\begin{array}{lrl}\text { Department of Human } \\
\text { Settlements (DHS) }\end{array}$ & $\begin{array}{l}\text { To establish sustainable human settlements, provide rental housing for the poor, maintain housing } \\
\text { institutions and provide housing subsidies }\end{array}$ \\
\hline Department of Transport & $\begin{array}{l}\text { To place transport at the heart of South Africa's economic and social development. The department } \\
\text { wants to ensure that through the provision of integrated transport systems, it can create an enabling } \\
\text { environment for sustainable economic and social development }\end{array}$ \\
\hline $\begin{array}{l}\text { Department of Public Works } \\
\text { (DPW) }\end{array}$ & $\begin{array}{l}\text { To provide government infrastructure and play a key role in providing an enabling environment. DWP is } \\
\text { involved in government accommodation, housing, land and infrastructure provision. The main } \\
\text { programmes the DWP is involved in are the EPWP, National Maintenance programme (NMP), } \\
\text { Contractor Incubator Programme (CIP), Infrastructure Delivery Improvement Programme (IDIP), Capital } \\
\text { Works Programme (CWP), the Inner-city Regeneration Programme (ICRP) and the Service Delivery } \\
\text { Improvement Programme (SDIP) }\end{array}$ \\
\hline $\begin{array}{lcc}\text { Department of } & \text { Social } \\
\text { Development (DSD) } & \end{array}$ & $\begin{array}{l}\text { To provide comprehensive social services which protect the poor and vulnerable, create an enabling } \\
\text { environment for sustainable development, and deliver quality services to improve quality of life }\end{array}$ \\
\hline
\end{tabular}




\begin{tabular}{|l|l|}
\hline $\begin{array}{l}\text { Department of Environmental } \\
\text { Affairs }\end{array}$ & $\begin{array}{l}\text { The focus is on environmental management, conservation and protection of the physical environment } \\
\text { and natural resources }\end{array}$ \\
\hline $\begin{array}{l}\text { Department of Public Services } \\
\text { and Administration (DPSA) }\end{array}$ & $\begin{array}{l}\text { To provide an effective and efficient development-orientated public service including all spheres of } \\
\text { government. The DPSA also assists rural local government in improved service delivery }\end{array}$ \\
\hline The Presidency & $\begin{array}{l}\text { For the focus of this research, the National Planning Commission (NPC), is listed. The NPC completed } \\
\text { the National Development Plan (NDP) in 2012, a national strategic plan for development from 2012 to } \\
\text { 2030. The aim is to eliminate poverty and reduce inequality by } 2030 \text { through maximising the people of } \\
\text { South Africa's resources, growing an inclusive economy, building capacities of government, and } \\
\text { working with business to solve complex problems }\end{array}$ \\
\hline
\end{tabular}

\section{Source: own compilation}

National government needs to consider rural development and LED as significant goals to achieve, and re-prioritisation is needed. The DRDLR, DTI and COGTA have made some effort to facilitate and co-ordinate rural and LED implementation. Improved inter-departmental and cross-sector collaboration is required at an accelerated pace, while national and local capacity needs to be increased, especially in rural areas (Rogerson, 2009).

The following section will attempt to provide some solutions for rural development.

\section{Rural Classifications}

Successful rural development requires a holistic approach, which includes components such as the local economy, social environment, the physical environment, and the political environment. If utilised in conjunction with LED and spatial planning in an integrated manner, it provides a rural area with the best opportunity for development. LED and spatial planning initiatives, have shared objectives, which include the creation of an enabling environment and promotes economic and entrepreneurial development, the creation of sustainable job opportunities, the provision of basic needs to the local communities, and improved quality of life. Both LED and spatial planning are intervention tools by the public sector to re-direct development where there are market failures.

The success of the rural development process depends on a number of factors, but local partnership formation is vital. Rural development is a team effort consisting of local government, the private sector/business sector and the local communities. The utilisation of local knowledge will also improve the quality of policy interventions. Every rural area has unique locations, resources and environments, which require best fit policies. Many areas adopt a one-size-fits-all approach because of a lack of the understanding of local areas, which does not lead to long term benefits for local rural communities.

Any region has a core or node with a periphery or hinterland. Regions could be classified as "leading" or "lagging" regions (Nelson, 1993). The locality of land uses and economic activities depends on access and movement corridors, locality of markets, locality of natural and human resources, and locality of the region with regard to geographical features and in relation to other regions. In the classification of rural regions, various degrees of 'ruralness' could be listed from very isolated and remote regions known as deep rural areas, to rural regions on the periphery of large metropolitan areas termed as near of fringe rural areas. In the formulation of classifications, it should be kept in mind that rural areas have urban nodes and centres, and even metropolitan regions have rural areas. Table 2 provides a classification of rural regions.

Table 2: Proposed rural regional classification in South Africa

\begin{tabular}{|c|l|}
\hline Type Of Region & \multicolumn{1}{c|}{ Characteristics Of The Region } \\
\hline Deep rural region & Located in a compromised geographical location, for example very mountainous areas, and isolated in terms \\
& of distance and access. \\
& Located at four hours or more driving distance to a major metropolitan region. \\
& No clear primary node, but a number of small service centres in the form of small villages. \\
& More than 90 percent of land uses and economic activities involved in agricultural and/or primary sectors. \\
& - Examples include the central and southern parts of Kwa-Zulu/Natal Province and the remote rural areas of \\
& the Eastern Cape Province and North-West Province. \\
\hline
\end{tabular}




\begin{tabular}{|l|l|}
\hline \multicolumn{1}{|c|}{ Type Of Region } & \multicolumn{1}{c|}{ Characteristics Of The Region } \\
\hline Rural region & - Isolated in terms of distance and access, but less so than a deep rural region. \\
& Located two to four hours driving distance from a major metropolitan area. \\
& Rural nodes in the form of medium to small rural towns as service centres, with a clearly defined hierarchy of \\
& nodes, a primary node and connectivity corridors. \\
& More than 75 percent of land uses and economic activities involved in agricultural and/or primary sector. \\
& An example is part of the southern Free State Province. \\
\hline $\begin{array}{l}\text { Fringel peripheral } \\
\text { rural region }\end{array}$ & Strategically located on the fringe or periphery of an urban region. \\
& - Located within a two hour or less driving distance from major metropolitan areas. \\
& Allows for economic opportunities in sectors other than agricultural. \\
& - Less than 50 percent of land uses and economic activities involved in agricultural and/or primary sector. \\
& - Strong hierarchy of nodes and corridors - nodes range from large rural towns to small rural towns. \\
& An example is the northern Free State region (Fezile Dabi District Municipality). \\
\hline $\begin{array}{l}\text { Urban } \\
\text { metropolitan region }\end{array}$ & Comprises mainly urban areas in the form of large metropolitan cities, with rural areas dispersed along the \\
& periphery of the region. \\
& Less than 30 percent of land uses and economic activities involved in agricultural and/or primary sector. \\
& Examples include the Gauteng City region, the Durban functional region and the Cape Town/Cape Flats \\
& region. \\
\hline
\end{tabular}

Source: Author's own compilation.

\section{A Rural Development Model}

A number of attempts have been made regarding LED and rural development models in order to develop, redevelop or revitalise rural areas. Table 3 is a summary of some of the main models available regarding LED/rural development processes.

Table 3: Summary of the main LED/rural development models

\begin{tabular}{|c|c|}
\hline Organisation & Model/Process \\
\hline $\begin{array}{l}\text { DPLG: LED resource book for municipal councillors } \\
\text { and officials, } 2003 \text { (DPLG, 2003) }\end{array}$ & $\begin{array}{l}\text { No specific step-by-step process. } \\
\text { Aspects include sectoral strategies, outcomes and target formulation, } \\
\text { public participation, data collection surveys. }\end{array}$ \\
\hline $\begin{array}{l}\text { The Presidency: Towards an anti-poverty strategy for } \\
\text { South Africa (The Presidency, 2008) }\end{array}$ & $\begin{array}{l}\text { No specific step-by-step process. } \\
\text { Aspects include economic sectoral strategies, social development } \\
\text { strategies such as education, health, provision of basic needs, social } \\
\text { cohesion. }\end{array}$ \\
\hline $\begin{array}{l}\text { The World Bank and support partners: Investigation of } \\
\text { pro-growth and pro-poor LED in South Africa (World } \\
\text { Bank, 2006) }\end{array}$ & $\begin{array}{l}\text { The investigation listed a specific research methodology when doing } \\
\text { LED/rural strategy formulation. }\end{array}$ \\
\hline $\begin{array}{l}\text { Australia South Africa Local Government Partnership } \\
\text { (ASALGP): A handbook for officials about LED } \\
\text { (ASALGP, 2005) }\end{array}$ & $\begin{array}{l}\text { A seven-step process, namely allocation of responsibility, engagement of } \\
\text { stakeholders, collection of data, involvement of public, analyse data, } \\
\text { develop action plans. }\end{array}$ \\
\hline $\begin{array}{l}\text { US Dept of Housing and Urban Development: } \\
\text { Economic development toolkit (US Dept of Housing } \\
\text { and Urban Development, 2010). }\end{array}$ & $\begin{array}{l}\text { A 10-step process, namely assessment of existing conditions, local } \\
\text { resources and barriers, select goal and market sectors, determine } \\
\text { general approach, identify intervention activities, write mission statement, } \\
\text { prepare economic strategy, develop action plans for implementation, } \\
\text { monitor and evaluate plan. }\end{array}$ \\
\hline $\begin{array}{l}\text { UN-Habitat: Promoting local economic development } \\
\text { through strategic planning (UN-Habitat, 2005). }\end{array}$ & $\begin{array}{l}\text { A 10-step process, namely getting started, stakeholders and participation, } \\
\text { situation analysis, visioning, setting objectives, identifying and evaluation } \\
\text { of strategic options, action planning, plan implementation, monitor, } \\
\text { evaluate, adjust and modify. }\end{array}$ \\
\hline $\begin{array}{l}\text { LGSPA: Strategic local economic development } \\
\text { (LGSPA, 2009). }\end{array}$ & $\begin{array}{l}\text { A five-step process, namely organising the effort, local economic } \\
\text { assessment, formulating, implementing and reviewing the strategy. }\end{array}$ \\
\hline $\begin{array}{l}\text { Swinburn, Goga and Murphy: Local economic } \\
\text { development: A primer developing and implementing } \\
\text { local economic development strategies and action }\end{array}$ & $\begin{array}{l}\text { A five-step process, namely organising the effort, local economic } \\
\text { assessment, strategy making, implementation and review. }\end{array}$ \\
\hline
\end{tabular}




\begin{tabular}{|l|l|}
\hline \multicolumn{1}{|c|}{ Organisation } & \multicolumn{1}{|c|}{ Model/Process } \\
\hline $\begin{array}{l}\text { Oklahoma State University: Blueprints for your } \\
\text { community's future: Creating a strategic plan for local } \\
\text { economic development (Oklahoma State University, } \\
\text { 2008). }\end{array}$ & $\begin{array}{l}\text { A 10-step process, namely begin the process, engage local community, } \\
\text { form an organised structure, conduct community assessments, develop } \\
\text { strategic plan, seek community feedback, implement plan, evaluate effort, } \\
\text { celebrate the success and create an ongoing process. }\end{array}$ \\
\hline $\begin{array}{l}\text { Planning LED: Theory and practice by Blakely and } \\
\text { Bradshaw, 2002 (Blakely \& Bradshaw, 2002). }\end{array}$ & A step-by-step process for compilation of a LED strategy. \\
\hline
\end{tabular}

Source: Author's own compilation from various sources as listed in the table.

In designing a model for rural development strategy formulation, the above listed attempts by other organisations and researchers have formed the basis of this newly-formulated model. The proposed model, named the Feza iSimangaliso model, which is the isizulu term for achieving a miracle, is based on the strategic planning process. It is a step-by-step process for compilation of a rural development strategy. Although it is accepted that every rural locality is unique with different challenges and opportunities, which requires a "best fit" process, the aim of the model is to provide a basic guideline for rural development implementation country-wide. The model follows the principles of participation and partnership promotion, with an integrative approach linking spatial planning with economic planning.

Figure 1 lists the various steps in the process, with a detailed description contained in Meyer (2013).

Figure 1: Summary of ten step "Feza iSimangaliso" rural development model

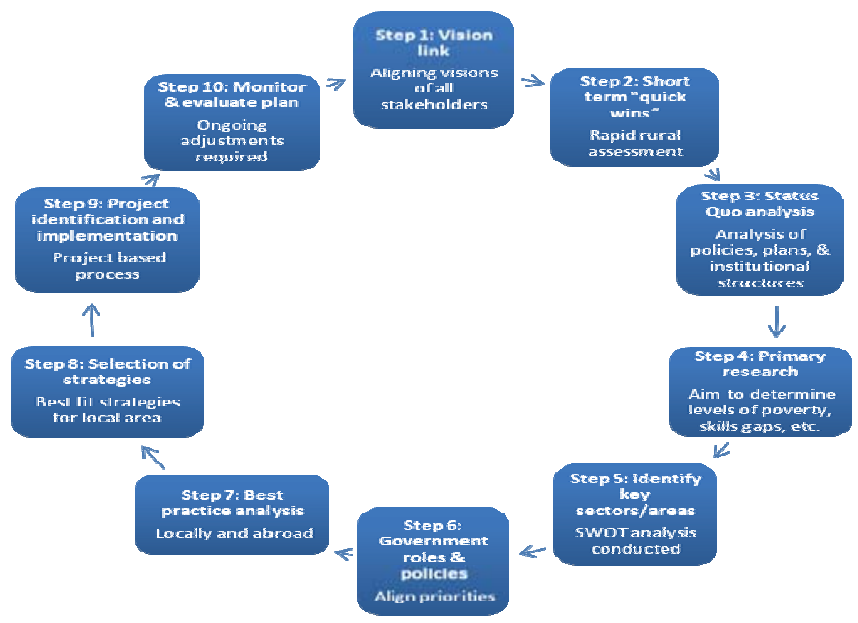

Source: Author's own figure.

\section{Rural Best Practice Solutions}

The following section is a rural development best practice analysis regarding processes, approaches and methods.

\subsection{Role of government}

The requirements of the development state are to ensure a stable political environment, good governance, implementable policies, assistance with the creation of jobs through an enabling economic environment, support for the informal sector of the economy, and a safety net for the poor. Best practice principles for rural development include the decentralisation of local decision making, skills development, the dissemination of information, formulation of measurable benchmarks such as targets and outcomes, and audits through monitor and control actions.

Government, as one of the role players, has a major role to play in rural development. Strong partnerships with the local community and business are also required. Institutional best practice initiatives that need to be included are the establishment of local LED units and local development agencies. Government needs to prioritise rural development and 
define the roles of the various spheres of government to ensure effective implementation, and limitation of duplication. A single national department, linked to provincial and local government initiatives, needs to lead and coordinate rural development. The "big push theory" proves that increased coordination leads to dynamic rural development. Government success in rural development requires it to have capacity and skills and provide an enabling environment. Political stability and commitment is just as important as economic and social stability. The focus of government subsidisation programmes should be housing delivery, tourism development, infrastructure development and agriculture support through incentives.

\subsection{Local leadership and partnership formation}

Local leadership is critical for rural development success. The term local leadership includes members of local stakeholders, namely government, local communities and the private sector. The partnership of these local stakeholders is a potential dynamic driving force behind rural development initiatives. Government leaders are expected to take the lead in coordination and facilitation, but other leaders from the community and business must contribute. The term local leadership contains two other terms, namely local champions and local drivers. Examples of local champions are local government officials such as the municipal manager, LED manager, the mayor and ward councillors, local ward committee members and CDWs, local business leaders, NGOs leaders and church leaders. Local leaders and champions must work together as partners to maximise local resources and actions. Local leaders must create momentum and make sure the local economy is driven. They must put communities first and facilitate participation by all stakeholders. Local government must take quick and effective decisions to the benefit of the local community. Local developmental projects driven by local business and local communities have more chance to succeed than projects attempted by government alone.

\subsection{Spatial planning}

Spatial planning is based on the strategic planning process and is, therefore, vision-based, giving direction in local economic planning, which must be integrated with spatial planning. This integration will ensure the spatial and geographic grounding of economic activities at optimal localities within a region. Spatial planning is integrative in nature and aims to ensure integrated land use planning to address spatial imbalances of the past, assist in the creation of enabling environments, improve economic rural-urban linkages through development corridors, ensure compact urban areas, support active participation, and ensure sustainable environments with a sense of place and viable local communities.

\subsection{Economic development and job creation}

Inclusive economic development, leading to growth with jobs (inclusive growth), is required for any successful region. Jobs lead to improvement in quality of life and development. Ultimately, the goal is for economic development to grow faster than population growth, leading to an increase in per capita income. For rural economies to grow more people need to be working, the working age population needs to increase (less youth and less senior citizens), and productivity needs to increase through skills development and technological progress. Economic sectors that have the potential for labour intensive job creation (job driver sectors) need support; which will lead to a diversified economy. These sectors include manufacturing, mining, tourism, agriculture including agro-processing, the green economy and retail.

\subsection{Agriculture}

In a rural region, agriculture is usually the dominating economic sector. Agriculture is a labour intensive economic sector with the potential to create jobs, and which plays a key role in food security. Agricultural sub-sectors that require intensive labour include the sugar cane industry, citrus, cotton, apples, pears, and vegetables. Agricultural development includes agrarian transformation, land reform and environmental management. Improved productivity requires agricultural interventions such as the provision of irrigation and hydro-phonic systems and fertiliser, training and mentorship, and land, market and product research. Emerging farmers and commercial farmers need to be protected and supported. Emerging farmers especially need support in access to land, mentorship from commercial farmers, access to markets, skills development and finance. 


\subsection{Tourism}

The tourism sector, as a labour intensive economic sector, provides for economic opportunities within a rural region. This sector has been the salvation of a number of rural regions and towns and could be successful in reasonable accessible, naturally attractive environments. Tourism is an important rural economic sector because it is labour intensive, assists with food security, plays a role in linking the region to other regions and assists in protecting the local environment. Tourism also plays the following vital roles in a regional economy, it strengthens local supply chains, assists with SMME development, promotes local arts and crafts, and encourages the formation of partnerships and diversification of the regional destination.

\subsection{Role of rural nodes}

Rural nodes of towns act as service centres within a region, but also play a key role as catalysts for development of the region. Globally, rural towns have been neglected, but governments are now realising the importance of rural towns in regional development. The development potential of a rural town depends on a number of factors, which could be placed in a matrix to test the development potential of rural towns. The main factors include locality, climate, geographical and environmental attractiveness, quality of soil and land, accessibility of town, level of economic diversity, social cohesion, level of entrepreneurship, availability of services, and quality of spatial planning.

\subsection{Rural-urban linkages}

The successful development of a region depends on the strengths of the linkages between nodes within the region, and between the rural areas and nodes in the region. External linkages to other regions and nodes within other regions are also important, and will assist in strengthening the economic base of the region. Linkages also include social and cultural linkages. Rural policies to strengthen rural-urban linkages include industrial linkages, migration policies, and rural urbanisation policies. Infrastructure development is a tool in the improvement of the linkages and integration of regions. The aim is to establish a regional economy with integrated nodes and rural areas linked with development corridors.

\subsection{Local resource utilisation}

Rural regions need to maximise the local and in most cases limited resources. Local resources include natural resources such as minerals and water, man-made resources such a local infrastructure, and local human resources. Local human resources need improvement by means of skills development and the provision of skills training in locally required skills, including technical and business skills. As part of the establishment of a local enabling environment, a quality environment is important, as it will attract people and businesses to the region. Local SMMEs, entrepreneurship and youth development needs to be encouraged.

\subsection{Housing}

Rural housing projects should be seen as flagship projects with a major impact on local receiving communities. Housing projects, if implemented effectively, must be a community driven and a benefitting process, example in the form of a people's housing project (PHP). In this way, a housing project will include skills development for local contractors, and have a strong job creation component, ultimately leading to the improvement of quality of life of local communities.

\subsection{Local community involvement and indigenous knowledge}

Local communities must be part of local decision making, planning, implementation and ownership of projects, thereby taking their destiny into their own hands. Local communities must be allowed access to ownership of projects, community facilities, housing and land. The quality and intensity of local community participation determines the level of rural development. Rural communities have higher levels of community involvement and social cohesion than highly urbanised areas; a sense of community and belonging that is one of the comparative advantages that cities do not generally have and which could attract city dwellers. A strong and healthy rural community must have modern ICT, strong levels of entrepreneurship, availability of jobs, export sectors with a strong economic base, social cohesion, industrial 
specialisation, inter-firm collaboration and good governance.

\subsection{Basic needs and social-welfare}

Rural development is not only about economic development, but also improvement of the quality of life of people. The provision of basic needs and social-welfare facilities forms the pro-poor component of rural development, and quality services are important for rural areas to compete with cities. As part of any rural development strategy, a community development plan needs to be included with specific projects. The lack of basic needs keeps people trapped in poverty and the provision of basic needs enables local rural people to achieve social and economic success. These basic needs include nutrition, health care, water, sanitation, shelter, education, access to land, and the ability to find work. The poor need protection in the form of safety nets, which include pension, social grant, housing subsidy, and access to services and finance.

\section{Conclusions}

The contribution of rural regions and the agriculture sector are pivotal for economic growth, food production and security, social cohesion and political stability. The global tide is slowly turning to an increased interest in rural development and rural areas. Reasons for this new discourse in rural attractiveness are over-population and congestion of metropolitan and large urban areas, global climate changes, globalisation and technological advances leading to space shrinking, an increasing need for food, land, and a sense of belonging, and sustainable development initiatives. These and other factors are providing momentum to this renewed focus on rural development. To reduce rural poverty, the focus of policies should be on the transfer of assets such as fixed property, and the access to economic opportunities, education and basic needs. Local community assets and resources should not be just redistributed, but new investment is required.

There has been a rural development paradigm shift over the last few decades. This has been from an agriculturalfocused rural development policy with a narrow approach on farming and food security, to an integrated rural development approach including a multi-sectoral attitude, diversification of the economy, value-added processes, and an attractive rural environment with strong local community development and decentralised decision-making processes.

The vision of a rural development strategy should focus on job creation, economic stability, diversification of the economic base and quality community facilities (Blakely \& Bradshaw, 2002). Rural development is an integrated and comprehensive war on poverty, unemployment and inequality, which includes all aspects of society inter alia social, economic, political, spatial, environmental, cultural and institutional components. Rural development strategies and policies must be people-centred with projects driven by local communities. Local people must decide on their own destiny and should be involved in the identification, planning, implementation and the taking of ownership of rural development initiatives, which should have a spatial grounding. A balance between pro-poor and pro-growth strategies is required. People will only be able to escape the poverty gap if their basic needs are provided for and they have access to assets.

A rural region will develop if the rate of economic development (not economic growth) exceeds the population rate. Economic development must lead to improved quality of life of all residents of a region, which is achieved through access to basic needs leading to social and economic freedom. Usually, rural areas and the agricultural sector are seen in a negative light, and industrial development is seen as the solution to economic development. This viewpoint has been proven incorrect, and a balanced economic developmental sector approach is required. The "big push theory" requires a nation to come together and unite with one vision; this unity must be on such a level that dynamic cooperation and coordination will lead to high levels of economic development.

\section{References}

ANC see African National Congress.

African National Congress (ANC). (1994) Reconstruction and development programme (RDP). A policy framework. Johannesburg: Umanyano.

ASALGP see Australia South African Local Government Partnership.

Ashley, C., \& Maxwell, S. (2001) Rethinking rural development. Development policy review, 2001, 19(4):395-425.

Australia South Africa Local Government Partnership (ASALGP). (2005). A handbook for provincial and municipal elected and appointed officials about local economic development. Web access: www.devplan.kzntl.gov.za/ASALGP. Date of access: 21 Feb 2013.

Bester, C.W. (1994) The consequences of urbanization and westernization on black family life in South Africa. Journal for Social Work, 30. 
Blakely, E.J. \& Bradshaw, T.K. (2002) Planning local economic development: theory and practice. 3rd edition. California: Sage.

Buxton, E.B. (1976) Delivering social services in rural areas. In Ginsberg, L.H. Ed. New York: Council for Social Work Education.

Chabane, C. (2010) South Africa set for new growth path (NGP). Web access: http://www.southafrica.info/business/economy /policies/growth-271010.htm. Date of access: 31 Mar 2011.

COGTA see Department of Cooperative Governance and Traditional Affairs

Davis, J. (2004) Using the Rural economic and enterprise development (REED) framework for analysis and joint action: implications for spatial development. Natural Resources Institute (NRI). Web access: www:http://www.nri.org. Date of access: 25 Jun 2012.

De Satge, R.( 2010) Rural development in South Africa. Johannesburg: Phuhlisani Publishers.

Delius, P. \& Schirmer, S. (2001) Towards a workable rural development strategy. Trade and Industrial Secretariat (TIPS). Johannesburg: University of Witwatersrand.

Department of Cooperative Governance and Traditional Affairs (COGTA). (2010) Strategic plan 2009-2014. Pretoria: Government Printer.

Department of Provincial and Local Government (DPLG). (2003) Local economic development. A resource book for municipal councillors and officials. Pretoria: Government Printer.

Department of Rural Development and Land Reform (DRDLR).( 2010a) A study on the revitalization of rural towns and regions in South Africa. Pretoria: Government Printer.

Department of Rural Development and Land Reform (DRDLR). (2010b) Comprehensive rural development strategy (CRDP). Pretoria: Government Printer.

Djukanovic, V. \& Mach, E.P. (1975) Alternative approaches to meeting basic Health needs in developing countries. UNICEF/WHO study. Geneva: World Health Organization.

DPLG see Department of Provincial and Local Government.

DRDLR see Department of Rural Development and Land Reform.

Duxbury, N., Campbell, H. \& Keurvorst, E. (2009) Developing and revitalizing rural communities. Toronto: Creative City Network of Canada.

Heimann, C. (2010) Comprehensive rural development programme. Presentation by Chief Director of Dept of Rural Development and Land Reform. ISAD multi-stakeholder forum. 25 Feb 2010.

Hemson, D. (2004) Rural development, the provision of basic infrastructure services. Integrated Rural and Regional Development. Pretoria: HSRC.

Henson, S. (2006) New markets and their supporting institutions. Washington: World Bank.

Herrick, B. \& Kindleberger, C.P. (1995) Economic Development. 4th ed. London: Mc Graw-Hill.

IFAD see International Fund for Agricultural Development.

IIED see Institutional Institute for Environment and Development.

International Fund for Agricultural Development (IFAD). (2011) Enabling poor rural people to overcome poverty. Rural poverty report, 2011. Web access: www.ifad.org/rpr2011. Date of access: 23 Sept 2011.

Institutional Institute for Environment and Development (IIED). (2000) Rural planning of South Africa: a case study. Web access: www.iied.org. Date of access: 10 Aug 2011.

Kakumba, U., \& Nsingo, S. (2008) Citizen participation in local government and the process of rural development. The rhetoric and reality in Uganda. Journal of public administration, 43(2). Jun 2008.

Kenyon, P. (2008) Rural revitalization and the need to create sustainable, healthy and resilient communities. Bank of ideas. Web access: www.bankofideas.com.au. Date of access: 23 Jan 2012.

LGSPA see Local Government Support Program in ARMM.

Local Government Support Program in ARMM (LGSPA). (2009) Strategic local economic development: a guide for local governments. Davao City, Philippines.

Makhura, M.N. (2004) Economic perspective to indigenous knowledge in rural development. SARDQ, 2(4), Oct - Dec 2004.

Meyer, D.F. (2013) An exploration of rural development strategies:the case of the northern Free State. Vanderbij|park: NWU. (Thesis $\mathrm{PhD})$.

Mokopanele, T. (2006) Poverty in SA. Star. 13 Jul. p4.

Myrdal, K.G. (1957) Economic theory and underdeveloped regions. London: Duckworth Publishers.

National Resource Institute (NRI). (2004) Small rural towns and local economic development: Evidence from two poor states in India. Paper presented at the international conference on local development, Washington, 16 - 18 Jun.

Nationmaster. (2011) People statistics. Web access: www.nationmaster.com/graph. Date of access: 8 Dec 2012.

Netshitenzhe, J. (2011) Addressing challenges of poverty. UJ Colloquium on poverty by J. Netshitenzhe, Executive Director: MISTRA, 21 Jul 2011.

NRI see National Resources Institute.

OECD see Organization for Economic Cooperation and Development.

Oklahoma State University. (2008) Blueprints for your community's future: creating a strategic plan for local economic development. Oklahoma: Oklahoma State University.

Organization for Economic Cooperation and Development (OECD). (2006a) Investment in priorities for rural development. Conference held in Edinburgh, Scotland, 16 - 19 Oct 2006.

Organization for Economic Cooperation and Development (OECD). (2006b). Reinventing rural policy. Observer. Oct 2006. 
Organization for Economic Cooperation and Development (OECD). (2007) Competitive cities: a new entrepreneurial paradigm in spatial development. Web access: www.oecd.org/rights/. Date of access: 12 Apr 2011.

Rogerson, C.M. (2009) Strategic Review of local economic development in South Africa. Final report submitted to Minister S Shiceka of Department of Development Planning and Local Government (DPLG). Commissioned by DPLG and GTZ. May 2009.

Sibisi, S. (2009) Brushing against the grains of history: making local economic development work in South Africa. Development planning division, working paper series no 5. DBSA, Mar 2010. Midrand.

Swinburn, G., Goga, S. \& Murphy, F. (2006) Local economic development: a primer developing and Implementing local economic development strategies and action plans. Washington: The World Bank.

Tacoli, C., \& Sutterthwaite, D. (2002) The urban part of rural development: the role of small urban centres in their regional and local economies. Montpellier: IIED.

The Presidency. (2000) The integrated sustainable rural development strategy (ISRDS). Pretoria: Government Printer.

The Presidency. (2003) National spatial development perspective (NSDP). Pretoria: Government Printer.

The Presidency. (2008) Towards an anti-poverty strategy for South Africa. Pretoria: Government Printer.

The Presidency. (2011) Diagnostic report 2011. National Planning Commission (NPC). Pretoria: Government Printer.

Todaro, M.P., \& Smith, S.C. (2011) Economic development. 11th ed. Essex: Pearson Education.

UNDP see United Nations Development Programme.

United Nations Development Programme (UNDP). (2012) Triple wins for sustainable development. New York: Bureau for Development Policy.

UN-Habitat. (2005) Promoting local economic development through strategic planning. Nairobi.

US Department of Housing and Urban Development. (2010) Economic development toolkit. Web access: www.hud.gov. Date of access: 21 Feb 2013.

Wilkinson, K.P. (1986) The small town community: its character and survival. Pennsylvania: Pennsylvania State University.

World Bank. (1997) Taking action to reduce poverty in Southern Africa: development practice. Washington.

World Bank. (2006) Investigation of pro-poor local economic development in South Africa. Washington. 